\title{
固体物理学における中性子散乱とX線散乱〜個人的な経験
}

\author{
廣田 和馬
}

（東京大学物性研究所附属中性子散乱研究施設）

\section{Neutron and X-ray Scattering for Solid State Physics A Personal Matter}

Kazuma Hirota

Neutron Scattering Laboratory, Institute for Solid State Physics, University of Tokyo

\section{0}

\section{1. はじめに}

日本物理学会誌の 1991 年 12 月号は「中性子散 乱研究の新しい展開」という特集号である。 JRR-3M が本格的に稼働をはじめた時期であり, 特集全体に熱気がこもっていて，今読み返しても 面白い. 私は当時後期博士課程 2 年生で, 学位を 取ったら中性子散乱をはじめたいと思っていたこ ともあり，この特集号を繰り返し読んだ. その中 に藤井保彦先生の書かれた「中性子線とX線の相 補的利用」という記事がある[1]. はじめて読ん だときは，中性子散乱はおろかX線散乱もほとん ど経験がなかったのでよく分からなかったはずだ が， 1 年後に Brookhaven 国立研究所でその両方 を同時に勉強しはじめることになったときに，こ の記事は非常に役にたった. 自分のなかの「中性 子線とX線の相補性」に対する考え方の核を作っ た記事なので，その概略を紹介したい．計算の詳 細は，元の記事を参照していただきたい.

- 凝縮系の研究に有効な数 $₫$ の波長の中性子 (N) とX線（X) のエネルギ一はそれぞれ meV と $\mathrm{keV}$ のオーダーで, 5〜 6 析も異なる. 固体 内の素励起は meV オーダーなので, Nは非弾性 散乱現象として容易に観測できる (Nの優位性).

- 核散乱 $\left(b_{n}\right)$, 電荷散乱 $\left(b_{c}\right)$, 磁気散乱 $\left(b_{m}\right)$ の間には半定量的に以下のような関係が成り立つ.

$$
b_{n}(\mathrm{~N}) \sim b_{m}(\mathrm{~N}) \sim b_{c}(\mathrm{X}) \sim 10^{3} b_{m}(\mathrm{X})
$$

$\mathrm{N}$ では磁気散乱は容易である（Nの優位性）。

・吸収係数は（数 ̊の波長では）一般に

$$
\mu(\mathrm{N}) \sim 10^{-2 \sim-3} \mu(\mathrm{X})
$$

であり，NはXより $2 \sim 3$ 桁透過力が強い.

- JRR-3M と Photon Factory の試料位置でのフラ ックスは $1 \mathrm{~cm}^{2}$ あたりそれぞれ $\phi(\mathrm{N})=6 \times 10^{7}$ (個 $/ \mathrm{s} / \mathrm{cm}^{2} / 1 \%$ エネルギー幅）と $\phi(\mathrm{X})=10^{11}$ （個 $/ \mathrm{s} / \mathrm{cm}^{2} / 0.1 \%$ エネルギー幅）となる. 現実的に利用 できる粒子数を比較すると

$$
\phi(\mathrm{N}) \sim 10^{-4} \phi(\mathrm{X})
$$

となり, 放射光 X 線 (SRX) の方が 1 万倍も強い. そのため, SRX による $10^{-3} b_{c}(\mathrm{X})$ 程度の磁気散乱 やさらに弱いフォノンによる非弾性散乱の測定が 現実のものとなってきた（SRX の優位性）.

- $b_{c}(\mathrm{X})$ と異なり, $b_{n}(\mathrm{~N})$ は周期律表中で不規則な 原子番号 $(\mathrm{Z})$ ・アイソトープ依存性を示す。そ れらを利用して, 水素・重水素置換, 軽元素, 近 接 Z化合物の認識を行う（古典的な相補性）.

・Nが原子核，Xが電子分布によって散乱を受け る事を利用し，X-Nのデータから価電子分布を 求めることが可能 (構造解析での相補性).

・ Nと SRX の磁気 Bragg 散乱強度は同程度にな りうるが, SRX では運動量分解能が遥かにすぐ れている（SRXの優位性）.

- SRX の波長は連続的に変化させられる. それ を利用して, 共鳴散乱項と磁気散乱項の干渉によ る磁気共鳴散乱を起こすことにより,「特定の元 素」の磁気モーメントによる散乱強度を数倍から 数千倍に増加できる場合がある (SRXの優位性).

・電子のスピン磁気モーメントと軌道磁気モーメ ントは電磁波に対して異なった相互作用をするた め, 原理的には分離可能である (SRX の優位性).

藤井先生の記事の内容 - 中性子とX線のそ れぞれに優位性があり, それらの相補性もまた研 究に利用できる - は, 原則としては全くその 通りである。もちろん, 全ての観測手段は相補的 であるから, 中性子と NMR でもX線と電子線で も上の文章は成り立つ. それでも, とくに頻繁に 中性子とX線の回折・散乱法が比較されるのは, 実験手法に共通のバックグランドがあり, その両 方を使いこなすことが可能であると暗黙のうちに 了解されているからだろう.

ただ，私自身の実感では，「中性子とX線は， 少なくとも実験の現場では, かなり異なる手法で あって, 両方に精通して使いこなすことは極めて 
困難である」ということになる．それが具体的に どういうことなのかを述べる前に, 中性子とX線 を利用して行った研究例をあげることにする.

\section{2.中性子とX線による臨界現象の研究例}

中性子散乱も放射光 X線散乱も, はじめたのは 1993 年の 4 月である. 中性子は NIST の NBSR を, 放射光は BNL の NSLS を使った（NBSR は JRR-3M と, NSLS は Photon Factory とほぼ同規 模の施設である). 研究対象は構造相転移や磁気 相転移の近傍であらわれる"Two-length scales"問 題であった.これは $\mathrm{Tb}$ の反強磁性転移[2]や $\mathrm{SrTiO}_{3}$ の反強誘電転移 [3]の近傍で散漫散乱に2つの全 く異なる相関長 (Narrow component と Broad component）が同時に現れるという現象で, 現在 では表面からの応力場が数 $\mu \mathrm{m}$ から数百 $\mu \mathrm{m}$ とい う予期しなかったほど広い範囲で相転移を変化さ せてしまうためと理解されている。10 年前はそ のことがまだよく分かっておらず，実験的な検証 をする必要があった.このときに役にたったのは, 中性子線とX線での透過距離の違いとエネルギー 分解能の差異である.

$\mathrm{Tb}$ の場合, $7 \mathrm{~mm}$ 角ほどの大型単結晶と極めて 細く（300 $\mu \mathrm{m}$ 程度）しかも並行に絞った中性子 ビームを使い, 前方散乱に近い条件で実験するこ とによって，相関距離が長くなる部分（Narrow component）が表面近傍の数百 $\mu \mathrm{m}$ の厚さ（すで に「表面」ではないので"skin"と呼ぶ）に局在し ていることが分かった. Tb はらせん磁性なので $(0$ $0 l+\delta) （ l$ は偶数, $\delta \sim 0.1 ）$ に磁気 Bragg 反射が現 れ， $l=0$ とすると前方散乱になる. 2 軸・ 3 軸 型分光器では, 散乱べクトル $\boldsymbol{Q}$ に直角方向の運 動量分解能は $\boldsymbol{Q}$ にほぼ比例する. そのため(00

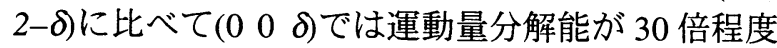
も改善され $\left(2 \times 10^{-4} \AA^{-1} \mathrm{HWHM}\right)$, 放射光 X線と も勝負できるようになる，X線では，共鳴磁気散 乱ができる波長で透過距離が数 $\mu \mathrm{m}$ しかないため, skin の部分しか見ることが出来ない. $100 \mathrm{keV}$ 程 度の高いエネルギーにすれば透過距離は飛躍的に 増大するが，共鳴磁気散乱による強度の増大は見 込めない．観測対象は散漫散乱なので非共鳴では 強度的に難しいのである．関連実験が Ho の薄膜 を使って行われたが，その場合は完全に放射光 X 線の独壇場であった。一般に磁性の場合，放射光 $\mathrm{X}$ 線は研究対象をきちんと選べば（specific）か なり有用なのだが, 中性子のように何にでも使え る（versatile）わけではない, といえる.

それに対して, $\mathrm{SrTiO}_{3}$ の場合は構造相転移であ るので, その散漫散乱はX線でもとらえることが 出来る. $\mathrm{SrTiO}_{3}$ の skin は $\mathrm{Tb}$ よりもずっと薄く数 $\mu \mathrm{m}$ から十数 $\mu \mathrm{m}$ であったため, 通常の大型単結 晶を使うと skin 対 bulk の体積比が小さくなり過 ぎてしまい, 中性子散乱では skin の部分の寄与 がはじめは見えなかった。これは単結晶を 10 枚 程度に薄くスライスしてそれを再び組み合わせる
ことで skin 体積比を増やすことで解決した．放 射光 X線では, 試料の断面に垂直でない散乱べク トルを使い, その周りに試料を回転させること (azimuthal scan) で，同じ Bragg 反射を「透過厚 さ」を変化させながら観測した．波長が決まれば 「透過距離」は一定だが，入射／反射角が変わる と「透過厚さ」は变化する.この実験で具体的に skin の厚さを見積もることができたのだが，最初 は放射光 X 線の運動量分解能が高すぎて Broad component をうまく捕まえられないという現象が 起きた. 放射光 $X$ 線の場合, $S / N$ 比と運動量分解 能を向上させるために検出器の前にアナライザー 結晶を置くことが多いのだが，この実験ではあえ てそれを外したりスリットを広げたりした。中性 子の 3 軸型分光器のようにモノクロやアナライザ 一結晶の状態やコリメーターによって分解能関数 が解析的に求まり, 実際の実験でも実験条件を広 い範囲で可変し, 正確に再現できる. しかし, 放 射光 $X$ 線の場合はそのような制御は極めて難しい 散漫散乱のように広い運動量空間に広がった散乱 関数を効率よく観測しようとすると放射光 X線で は分解能が高過ぎるということが起きてしまう. 幾分かは線源そのものが強いことで補償されるの だが，それなら始めから適切な分解能をもつた実 験室系のX線源を使った方がよい, ということも ありうる[4].

$\mathrm{SrTiO}_{3}$ の構造相転移はソフトモードの凍結によ るものだが, フォノンのソフト化にともなって実 際に転移する前に（つまりソフトフォノンの特性 周波数が有限のうちに）準弾性散乱的なピークが 現れることが知られている。これをセントラルピ ークとよぶ. セントラルピークと Narrow component/Broad component がどのような関係に あるかを調べる上で, 中性子とX線のエネルギー 分解能の違いを利用した. 熱中性子 3 軸型分光器 のエネルギー分解能は $\mathrm{meV}$ オーダーだが, $\mathrm{X}$ 線 の場合 $\mathrm{eV}$ オーダーであり, 事実上, 熱的現象に 対しては無限大と考えられる。したがって，X線 散乱では自動的にエネルギー積分が実行されるの に対し, 中性子散乱では弾性散乱部分だけを主に 観測することになる. 中性子散乱でも 2 軸モード にすることで, 低次元磁性体などの場合は近似的 にエネルギー積分を実行させることも可能[5]だ が, $\mathrm{SrTiO}_{3}$ のような構造相転移ではそのような手 法は使えない.

$\mathrm{SrTiO}_{3}$ の Two-length scale"問題は, 中性子とX 線を相補的に利用することで研究がうまくいつた 例である. 中性子とX線を使いはじめて最初に与 えられた課題が（その当時の自分には全然分から なかったが）適切に選ばれたものだったというだ けであり, 他の研究課題でも相補性がいつでも発 揮されるわけではもちろんない.これまで自分が 関与した論文のうち, 中性子関連が 56 編でX線 関連が 18 編だが, 単一の論文で両方を意図的に 使ったのは $\mathrm{SrTiO}_{3}$ の 1 編しかない. もちろん, 研究は一つの論文で終わるものではないので, 一 
連の研究のなかで中性子とX線の両方を利用した 課題はいくつかあるが，それならば電気抵抗や電 子線回折などの他の測定手段が相補的であるのと それほど変わらないことになる。

\section{3. 実験の現場で}

実際に実験を行ってみると, 放射光X線散乱と 中性子散乱ではかなり勝手が違うことが分かる (ここで取り上げるのは数 $\mathrm{mm}$ 角以上の大きさ をもった単結晶を使った実験なので, 粉末回折や 微小単結晶による構造解析では事情は全く異なる ことをあらかじめお断りしておく).

\section{・実験開始}

3 軸型分光器で中性子散乱をする場合, 実験の はじめにゴニオメーターの上で軸立てをしてアル ミ缶に封入してしまえば, 後は冷凍機などにセッ トしてすぐ実験が始められる. 複雑なアクセサリ 一を使うときは余分に時間と労力が取られるが, これはアクセサリーの操作の問題である. また, いったんアルミ缶に封入してしまえば, アクセサ リーをゴニオメーターに載せた後の調整程度で, 軸立ての手間はほとんどない. きちんとオフライ ンで準備しておけばマシンタイム開始 30 分後に はデー夕を取りはじめることも困難ではない。し たがって，1日だけ実験をする，ということも可 能となる.

放射光X線で 4 軸回折計を使う場合, 毎回装置 の較正が必要なため, 実験をはじめるのに短くと も数時間, 下手をすると数日かかる可能性がある

（個人的には朝 9 時に交代して, その日の真夜中 までにオーバーナイトスキャンをかけられれば上 出来だと思っている). まず試料位置にピンをた て，スコープで䙼きながら回転中心を出す．中性 子では縦 $4 \mathrm{~cm}$ 横 $3 \mathrm{~cm}$ のようなビームがくるが, 放射光では $1 \mathrm{~mm} \phi$ 程度なのでシビアなのである. 次に回転中心にあるピンにビームがあたるように する. それから，ようやく室温で試料の軸立てで ある.このときもあらかじめ散乱面をきちんとカ ットしておかないといつまでも Bragg ピークが見 えないことになる（分解能が高いため少しでも散 乱条件から外れると何も見えない)，このときビ 一ムの丁度中央に試料表面が来るようにしないと 逆格子の中心がずれてしまうので, ビームと試料 表面が平行な時にビーム強度が半分になるように する(これを「半割」という). 放射光ではビー ムを出すたびにインターロック付きのハッチを閉 じないといけないので, 中性子のようにビームを 出しながら脇でゴニオを手で回して，という訳に はいかない。軸が立ったら今度は冷凍機に取り付 けて，それを回折計に載せて再度軸立てである。 ここでも半割. それが終わったら, 今度はフライ トパスやスリットの設置である．X線の空気散乱 による減衰は馬鹿にならないので, フライトパス
を真空にしたり $\mathrm{He}$ ガスを流したりする. よく整 備されているビームラインでないと, フライトパ スの組み立てはほとんど借り物競走の様相を呈し てくる. それが終わると, 今度はアナライザーの 設置. その他にも高調波の混入を低隇させるため に回路の調整を行ったり, バックグランドを減ら すために隙間を鉛テープで塞いだりと作業が続く. 実験を始めるまでに 12 時間以上作業, というの はそのような事情による.それよりも深刻なのは, 複雑な準備作業の上に成り立っているために, 実 験条件を再現することがどうしても困難になる, ということである.

\section{·実験中}

3 軸型分光器での中性子散乱の場合, データ量 はそれほど多くならない. ラインプリンターに打 ち出される結果をスクラップブックに適宜貼付け ながら,デー夕を手で方眼紙にプロットしていく, というのは今でもかなり現実的で効果的な方法で ある. 観測する対象にあった分光器と実験環境の 条件を見い出したら（この部分が最も大切であり 困難なのだが), あとは必要なデー夕をためれば よい. 非弾性散乱などでは, 1 点 10 分で 1 スキ ヤン 5 時間などというのは普通なので, 実験はか なりゆっくりと進む. ビーム強度, 幅, 分解能な ぞの実験条件は定量的に再現可能なので, 長期に わたって研究が可能である（時間がかかるせいも あるが).

それに対して 4 軸回折計で放射光 X線の実験を すると, すぐにデー夕量が増えて行く. ラインプ リンターにログを打ち出したりしていると, すぐ に紙の束というか山になってしまう. 大抵は実験 ノートにスキャン番号とスキャンの内容を書いて インデックスを作り，それを頼りにデータプロッ トをすることになる. 手書きではもちろん間に合 わないし，スキャンごとに KaleidaGraph で処理 していても追い付かない，そこでマクロ言語を内 臓しているプロットプログラムを使って半自動的 にフィッティングとプロットを行うような仕組み を実験の初期の段階で作っておかないと, デー夕 の海に溺れてしまうことになる. ある程度, 実験 をしていくと自分や共同研究者の作った以前のマ クロを流用できるようになるが，そうなるまでは かなり苦労する.マクロ作成まで済んでしまえば, 実験にようやく集中できるようになる．ただ，そ こに行き着く前にマシンタイムが終わってしまう こともあり得る. 実験条件を定量的に再現するこ とはかなり難しい.

放射光では時間とともにリング電流が低下する （そのため強度もゆるやかに変化する）ので 1 日 に $1 ， 2$ 度リングに電子を注入する．低温実験の 場合, 試料温度がビーム強度によって変化するこ ともあるので，単にモニターで規格化すればよい 訳ではない．強いビームに曝されているモノクロ 結晶の温度が変化してビーム位置や波長が変わる 
こともある. NSLS で実験していたときには（か なり特殊な条件下での実験であったが), 数分の 単位で害験条件が変化してしまい Bragg ピークを 捕まえておくだけでも一苦労という場合もあった. この辺りの状況は中性子とX線というよりは, 定 常炉と加速器の違いかもしれない. とにもかくに も，放射光X線散乱では「体力」がものをいう.

\section{・実験試料}

中性子は透過力が強いが，これはつまり物質と の相互作用が弱く（これは利点でもある）, 実験 には大きな結晶が必要とされる, という問題を生 む.これは実際かなり深刻な問題であり, 試料が 小さいが故に諦めている研究がかなりある. とく に新物質開発の先端では大きな試料を作っている 余裕などは無いため, 中性子散乱だけがその分野 から取り残されるという事態が起こる. 中性子源 の強度そのものは 1960 年代に完成した BNL の HFBR（現在は停止）あたりですでに止まってい る. 冷中性子源の開発や, 中性子光学の発展によ ってより高い効率で中性子を取り出せるようにな ってきたので, 試料位置での強度は増加している が.

パルス中性子には発展の余地がまだあるが，X 線が固定陰極, 回転陰極, 放射光（第 $1 \sim 3$ 世代） と指数関数的に強度を増やしてきたようにはいか ないだろう.X線の場合, 自由電子レーザーなど によってさらに線源の強度が増加することが見込 まれている．また，放射光の場合，中性子のよう に立体角全体に広がる点光源ではなく, はじめか ら高い指向性をもっていることが大きな特徵とな つている. これが高輝度 (単位時間単位面積を通 過する電子数), 高運動量分解能 (平行度が高い) という特色をもたらす[6]. ビームサイズがもと もと小さいため大きな結晶を使う理由は, 試料の 取り扱いの容易さ, ということを除いてはほとん ぞない，試料体積の制約のために中性子では行う ことの出来なかった研究が, 磁気散乱や非弾性散 乱などX線にとっては必ずしも得意でない範囲も 含めて, 今後研究されていくことは間違いない. 新物質の研究もまた同様であろう.

\section{4. 雑感}

多少の語弊はあるかもしれないが，一言で言え ば，中性子は固体物理学にとって「素性の良い」 研究手段である. 数 ̊ の波長が十数 $\mathrm{meV}$ のエネ ルギーに対応し, 核散乱長は原子番号とともに複 雑に変化するが同じオーダーで, 磁気散乱長も同 程度, 物質との相互作用が小さいので試料に損傷 を与えることも無い.試料と時間が十分にあれば, 物質の静的・動的構造に関連することは, ほとん ど網羅することが可能である. 問題は, 試料と時 間は決して十分になることはない, という点であ ろう.したがって, いかに効率良く研究を行うか,
が重要となる.これには個々の研究者の能力だけ ではなく, 新しい実験手法の開発, 実験環境の整 備, 研究施設へのアクセスの向上, も含まれる.

一方, $\mathrm{X}$ 線（とくに放射光 $\mathrm{X}$ 線）は, 固体物理 学にとって中性子ほど素性はよくないが, 有り余 る強度（しかもまだ増え続けている）を背景に, 色々な分野に（中性子がこれまで引き受けていた 分野にも）進出している，と言える. 波長域によ っては透過距離が短くなる問題はあるが，通常は 数 $\mu \mathrm{m}$ 以上はあるので原理的にはバルクを観測し ていると考えられる。試料サイズなどの制約はほ とんどないが，むしろ強度が強すぎるために試料 を損傷させたり, 温度を上げてしまったり, とい うことが起こる. 運動量分解能は良すぎて困るぐ らいであり, 今後はいかに定量的に分解能を「悪 く」していけるかが重要になるだろう. また, 中 性子とは異なり, 実験室系のX線源をもてること も研究を行う上では大きな意味をもっている.

個人的な意見としては, 中性子とX線は今後ま すます「分化」していくのではないかと思ってい る. 中性子とX線を両方使うことではじめて可能 となる研究テーマはもちろんあるはずだが，一般 には, 一連の研究の流れのなかで様々な実験手段 が相補的に使われる，という意味での相補性のほ うがむしろ重要になってくるのではないだろうか. 分化が進めば進むほど, 両方の実験技術の先端に 精通し続けることは困難になってくる. 困難な部 分にこそ新しいものが潜んでいるのかもしれない が, さて, 私はどうしょうか.

\section{参考文献}

1 藤井保彦, 日本物理学会誌 46 (1991) 1056.

2 K.Hirota et al., Phys. Rev. B 49 (1994) 11967.

3 K.Hirota et al., Phys. Rev. B 52 (1995) 13195.

4 野田幸男, 菖蒲敬久, 池田直, 日本結晶学会誌 42 (2000) 12.

5 G.Shirane et al., Phys. Rev. Lett. 59 (1987) 1613.

6 岩崎博, 結晶解析ハンドブック（丸善 1999） 105. 